\title{
Pengembangan Sistem Administrasi Pengolahan Data KKN Universitas Diponegoro
}

\author{
Mastam Aji ${ }^{1)}$, Kodrat Iman Satoto ${ }^{2)}$, Rinta Kridalukmana ${ }^{2)}$ \\ Jurusan Sistem Komputer, Fakultas Teknik, Universitas Diponegoro \\ Jl. Prof. Sudharto, Tembalang, Semarang, Indonesia \\ Email: mastam_aji@yahoo.co.id
}

\begin{abstract}
KKN Program is the activity which is done by student. The activities shall be conducted as part of the student learning activities. In practice, there is a problem in the management of KKN's data, such as period data, district data, sub-district data, village data, Supervisor's data (DPL), zoning data, area history data, KKN participant data, preparation of a valuation and not centralized data. One of them is KKN Program which is conducted by Diponegoro University. KKN Program will require an application to manage data in order to improve work efficiency and the smoothness of KKN Program.

The application of KKN Data Processing Administration is a web-based application, created by use the $P H P$ programming language within the scope of the Code Igniter Framework and MySQL database. The development method is done by use the waterfall method, whereas in the application design is using UML modeling.

The results of this application design is the creation of a web-based application that can manage KKN data in the Diponegoro University, such as period data processing, district data, data sub-district, village data, Supervisor's data (DPL), zoning data, KKN participant data, list of participants, and the value of area history data that has been used in previous KKN program.
\end{abstract}

Keywords: KKN, administrative applications, $\mathrm{PHP}$ Framework Code Igniter.

\section{Pendahuluan}

$\mathrm{P}$ engolahan data KKN (Kuliah Kerja Nyata) yang belum efektif dan efisien menjadi latar belakang dibangunnya sistem administrasi pengolahan data KKN. Sistem informasi yang terkomputerisasi dapat membantu pengolahan data KKN seperti data Periode, data DPL (Dosen Pembimbing Lapangan), data kabupaten, data kecamatan, data desa, data mahasiswa, data pembagian wilayah serta data nilai peserta $\mathrm{KKN}$ untuk pembuatan laporan.

\section{LANDASAN TEORI}

\section{A. Sistem Informasi}

Sistem informasi dapat didefinisikan sebagai berikut : a. Suatu sistem yang dibuat oleh manusia yang terdiri dari komponen-komponen dalam organisasi untuk mencapai suatu tujuan yaitu menyajikan informasi. b. Sekumpulan prosedur organisasi yang pada saat dilaksanakan akan memberikan informasi bagi pengambil keputusan dan atau untuk mengendalikan organisasi.

c. Suatu sistem di dalam suatu organisasi yang mempertemukan kebutuhan pengolahan transaksi, mendukung operasi, bersifat manajerial dan kegiatan strategi dari suatu organisasi dan menyediakan pihak luar tertentu dengan laporan-laporan yang diperlukan.

Organisasi menggunakan sistem informasi untuk mengolah transaksi-transaksi, mengurangi biaya dan menghasilkan pendapatan sebagai salah satu produk atau pelayanan mereka. Bank menggunakan sistem informasi untuk mengolah cek-cek nasabah dan membuat berbagai laporan rekening koran dan transaksi yang terjadi. Perusahaan menggunakan sistem informasi untuk mempertahankan persediaan pada tingkat paling rendah agar konsisten dengan jenis barang yang tersedia.

Sebagian sistem informasi berlandaskan komputer terdapat di dalam suatu organisasi dalam berbagai jenis. Anggota organisasi adalah pemakai informasi yang dihasilkan sistem tersebut termasuk manajer yang bertanggung atas pengalokasian sumber daya untuk pengembangan dan pengoperasian perusahaan. (Bin Ladjamudin, Al-Bahra, 2005)

\section{B. Software Development Life Cycle}

SDLC atau Software Development Life Cycle atau sering disebut juga System Development Life Cycle adalah proses mengembangkan atau mengubah suatu sistem perangkat lunak dengan menggunakan modelmodel dan metodologi yang digunakan orang untuk mengembangkan sistem-sistem perangkat lunak sebelumnya (berdasarkan best practice atau cara-cara yang sudah teruji baik).

Tahapan-tahapan yang ada pada SDLC secara global adalah sebagai berikut :

a. Inisiasi (initiation)

b. Pengembangan konsep sistem (system concept development)

c. Perencanaan (planning)

d. Analisis kebutuhan (requirements analysis)

e. Desain (design)

f. Pengembangan (development)

g. Integrasi dan pengujian (integration and test) 
h. Implementasi (implementation)

i. Operasi dan pemeliharaan (operations and maintenance)

j. Disposisi (disposition)

(A.S, Rosa dan Shalahuddin, M., 2014)

\section{Model Waterfall}

Model SDLC air terjun (waterfall) sering juga disebut model sekuensial linier (sequential linear) atau alur hidup klasik (classic life cycle). Model air terjun menyediakan pendekatan alur hidup perangkat lunak secara sekuensial atau terurut dimulai dari analisis, desain, pengodean, pengujian, dan tahap pendukung (support).

Kenyataannya sangat jarang model air terjun dapat dilakukan sesuai alurnya karena sebab sebagai berikut

a. Perubahan spesifikasi perangkat lunak terjadi di tengah alur pengembangan.

b. Sangat sulit bagi pelanggan untuk mendefinisikan semua spesifikasi di awal alur pengembangan. Pelanggan sering kali butuh contoh (prototype) untuk menjabarkan spesifikasi kebutuhan sistem lebih lanjut.

c. Pelanggan tidak mungkin bersabar mengakomodasi perubahan yang diperlukan di akhir alur pengembangan.

Model ini sangat cocok digunakan kebutuhan pelanggan sudah sangat dipahami dan kemungkinan terjadinya perubahan kebutuhan selama pengembangan perangkat lunak kecil. Hal positif dari model air terjun adalah struktur tahap pengembangan sistem jelas, dokumentasi dihasilkan di setiap tahap pengembangan, dan sebuah tahap dijalankan setelah tahap sebelumnya selesai dijalankan (tidak ada tumpang tindih pelaksanaan tahap). (A.S, Rosa dan Shalahuddin, M., 2014)

\section{ERD}

Pemodelan awal basis data yang paling banyak digunakan adalah menggunakan Entity Relationship Diagram (ERD). ERD dikembangkan berdasarkan teori himpunan dalam bidang matematika. ERD digunakan untuk pemodelan basis data relasional. Sehingga jika penyimpanan basis data menggunakan OODBMS maka perancangan basis data tidak perlu menggunakan ERD. (A.S, Rosa dan Shalahuddin, M., 2014)

\section{E. $U M L$}

UML adalah bahasa spesifikasi standar yang dipergunakan untuk mendokumentasikan, menspesifikasikan dan membangun perangkat lunak. UML merupakan metodologi dalam mengembangkan sistem berorientasi objek dan juga merupakan alat untuk mendukung pengembangan sistem. UML saat ini sangat banyak dipergunakan dalam dunia industri yang merupakan standar bahasa pemodelan umum dalam industri perangkat lunak dan pengembangan sistem. (Gata, Windu dan Gata, Grace, 2013)

\section{F. Use Case}

Use Case Diagram merupakan pemodelan untuk kelakuan (behavior) sistem informasi yang akan dibuat. Use Case mendeskripsikan sebuah interaksi antara satu atau lebih aktor dengan sistem informasi yang akan dibuat. Dapat dikatakan Use Case digunakan untuk mengetahui fungsi apa saja yang ada di dalam sistem informasi dan siapa saja yang berhak menggunakan fungsi-fungsi tersebut. (Gata, Windu dan Gata, Grace, 2013)

\section{G. Sequence diagram}

Sequence diagram menggambarkan kelakuan objek pada Use Case dengan mendeskripsikan waktu hidup objek dan pesan yang dikirimkan dan diterima antar objek.(Gata, Windu dan Gata, Grace, 2013)

\section{H. Class diagram}

Class diagram merupakan hubungan antar kelas dan penjelasan detail tiap-tiap kelas di dalam model desain dari suatu sistem, juga memperlihatkan aturan-aturan dan tanggung jawab entitas yang menentukan perilaku sistem. Class diagram juga menunjukkan atribut-atribut dan operasi-operasi dari sebuah kelas dan constraint yang berhubungan dengan objek yang dikoneksikan. (Gata, Windu dan Gata, Grace, 2013)

\section{I. $P H P$}

PHP merupakan singkatan dari Hypertext Preprocessor yang merupakan bahasa berbentuk skrip yang ditempatkan pada server dan diproses di server. Hasilnya kemudian dikirimkan ke browser klien. (Hirin A.M dan Virgi, 2011)

\section{J. Javasript}

Javascript adalah bahasa yang berbentuk kumpulan skrip yang pada fungsinya berjalan pada suatu dokumen HTML. Sepanjang sejarah internet bahasa ini adalah bahasa skrip pertama untuk web. Bahasa ini adalah bahasa pemrograman untuk memberikan kemampuan tambahan terhadap HTML dengan mengijinkan pengeksekusian perintah-perintah di sisi klien, yang artinya di sisi browser bukan di sisi server. (Adi, A.P dan Sanjay, R., 2012)

\section{$K$. Code Igniter}

Code Igniter adalah aplikasi open source yang berupa framework dengan model MVC (model view controller) untuk membangun website dinamis. Dengan menggunakan PHP Code Igniter akan memudahkan developer untuk membuat aplikasi web dengan cepat dan mudah dibandingkan dengan membuatnya dari awal. (Wiswakrma, Komang, 2010)

\section{L. $M y S Q L$}

$M y S Q L$ adalah sebuah perangkat lunak sistem manajemen basis data SQL atau DBMS yang multithread, multi-user dengan sekitar 6 juta instalasi di seluruh dunia. $M y S Q L A B$ membuat $M y S Q L$ tersedia sebagai perangkat lunak gratis di bawah lisensi $G N U$ General Public Licence (GPL). Tetapi mereka juga 
menjual di bawah lisensi komersial untuk kasus-kasus di mana penggunaannya tida cocok dengan pengunaan GPL. (Wahyono, Teguh, 2009)

\section{PERANCANGAN Sistem}

\section{A. Tahapan Perancangan Sistem}

Tahapan perancangan sistem memiliki tujuan untuk men-desain sistem baru yang dapat menyelsaikan masalah-masalah yang dihadapi organisasi atau perusahaan. Software Development Live Cycle adalah proses mengembangkan atau mengubah suatu sistem perangkat lunak dengan menggunakan model-model yang digunakan orang untuk mengembangkan sistemsistem perangkat lunak sebelumnya. Model yang digunakan dalam penelitian tugas akhir ini adalah model waterfall. Model waterfall terdiri dari 5 tahap yaitu Analisis Kebutuhan, Desain, Pengodean, Pengujian dan Pemeliharaan

\section{B. Analisis Kebutuhan}

Tahapan analisis kebutuhan dilakukan untuk menspesifikasikan kebutuhan perangkat lunak agar dapat dipahami perangkat seperti apa yang diinginkan user dan kemudian mentransformasikan ke dalam sebuah deskripsi yang jelas dan lengkap.

1. Kebutuhan Pengguna

Setelah mendeskripsikan tahapan kerja dan disertai informasi serta kendala yang ada, didapatkan kebutuhan untuk kemudahan memanajemen data KKN Universitas Diponegoro. Kebutuhan tersebut adalah :

1. Mengelola data DPL KKN.

2. Mengelola data wilayah yang digunakan untuk KKN.

3. Mengelola data periode $\mathrm{KKN}$.

4. Mengelola data peserta KKN.

5. Mengelola data nilai akhir peserta.

6. Mencetak nilai dan laporan lolos/tidak lolosnya peserta.

7. Menampilkan history wilayah KKN yang digunakan pada periode sebelumnya.

2. Aktor yang Terlibat

Terdapat beberapa aktor yang terlibat dalam pembuatan aplikasi manajemen ini, yaitu :

1. Superadmin

Superadmin yang dalam hal ini adalah sekretaris pusat KKN yang memiliki wewenang untuk:

a. Mengelola data pengguna.

2. Admin

Admin yang dalam hal ini adalah pegawai KKN yang memiliki wewenang untuk:

a. Mengelola data DPL.

b. Mengelola data kabupaten.

c. Mengelola data kecamatan.

d. Mengelola data desa.

e. Mengelola data periode.

f. Mengelola data perserta KKN.

g. Mengelola nilai KKN.

h. Mengelola data wilayah. i. Mengelola data history wilayah yang digunakan sebelumnya.

3. TU (Tata Usaha)

TU yang dalam ini adalah pegawai bagian TU (Tata Usaha) jurusan dan program studi yang memiliki wewenang untuk:

a. Mengunggah data calon peserta KKN.

4. Mahasiswa

Mahasiswa dalam hal ini adalah peserta KKN yang memiliki kewenangan untuk :

a. Mencari data mahasiswa berdasarkan nim.

\section{Desain}

Tahap perancangan / desain perangkat lunak merupakan proses multi langkah dan berfokus pada beberapa atribut perangkat lunak. Proses ini berdasarkan dari analisa sebelumnya sehingga menciptakan sebuah rancangan yang sesuai dengan kebutuhan dari pihak terkait. Dalam perancangan perangkat lunak ini, digunakan Entity Relationship Diagram (ERD) untuk pemodelan basis data dan UML untuk pemodelan perangkat lunak.

\section{ERD}

Entity Relationship Diagram (ERD) adalah salah satu metode pemodelan data yang digunakan untuk menggambarkan suatu basis data.

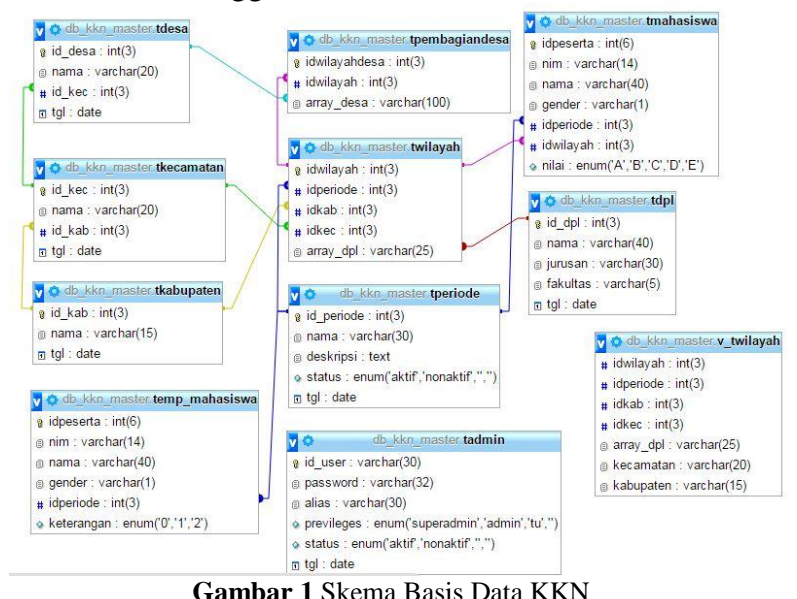

2. UML

a. Usecase Diagram

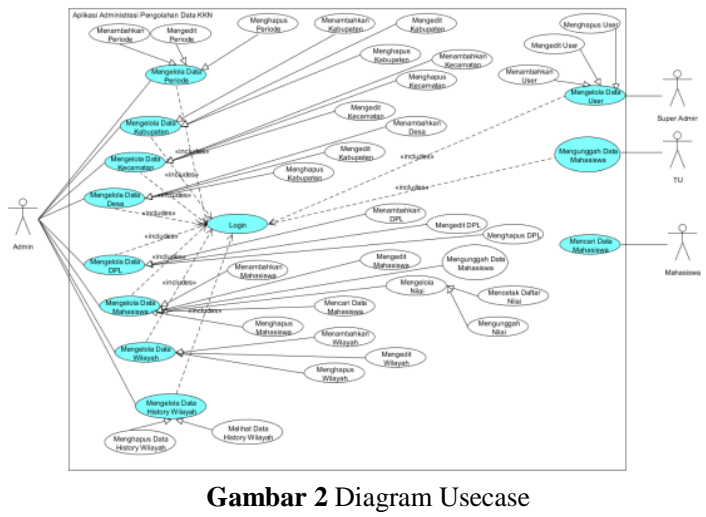

b. Class Diagram

Class diagram atau diagram kelas menggambarkan hubungan yang ada pada kelas-kelas pada aplikasi. Berikut merupakan 
diagram kelas aplikasi Administrasi Pengolahan Data KKN

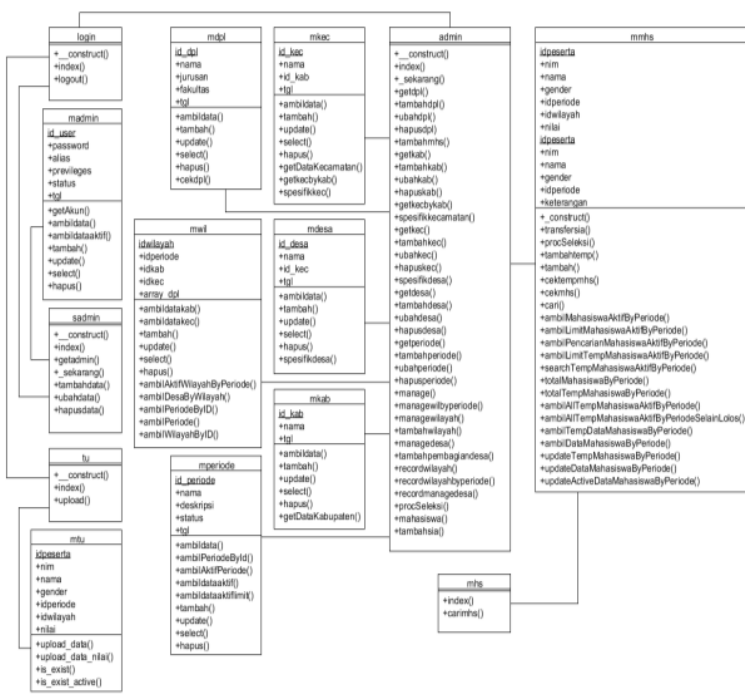

Gambar 3 Diagram Kelas Aplikasi Adminstrasi Pengolahan Data KKN

c. Sequence Diagram

Berkut ini adalah gambar-gambar Diagram Sequence dari Aplikasi Administrasi Pengolahan Data KKN.

Gambar 4 merupakan digram sekuensial untuk masuk ke sistem (login).

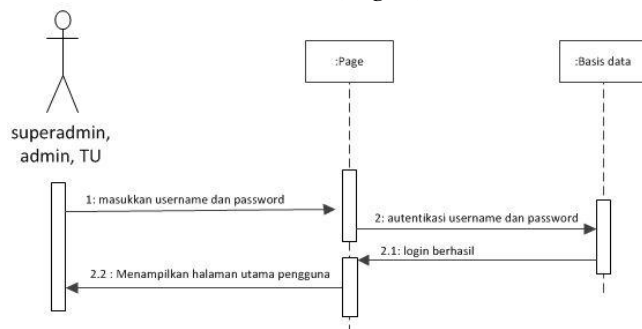

Gambar 4 Diagram sekuensial masuk ke sistem (login)

Gambar 5 merupakan digram sekuensial dari menambahkan data wilayah KKN.

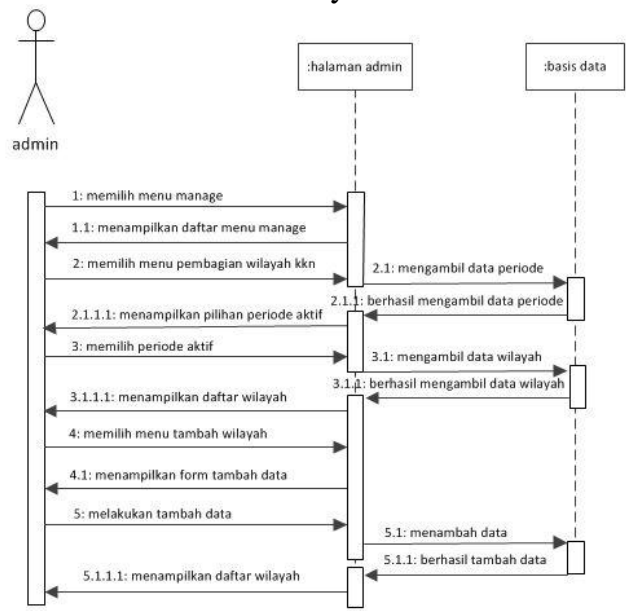

. Gambar 5 Diagram sekuensial dari menambahkan data wilayah KKN

Gambar 6 merupakan digram sekuensial dari melihat data history wilayah KKN.

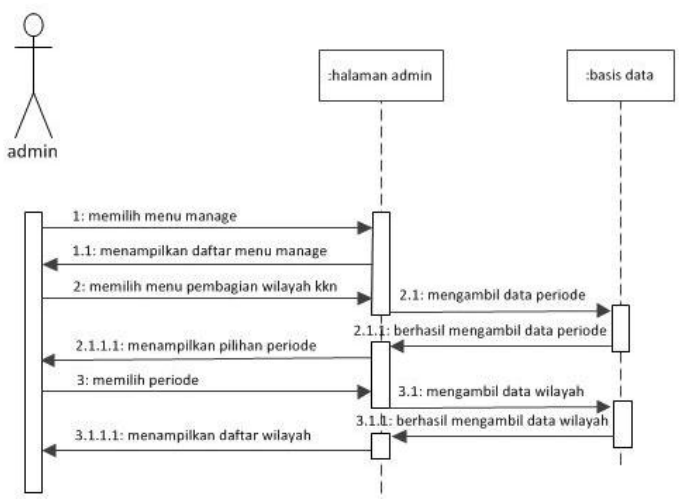

Gambar 6 Diagram sekuensial dari melihat data history wilayah $\mathrm{KKN}$

Gambar 7 merupakan digram sekuensial dari mengunggah data mahasiswa.

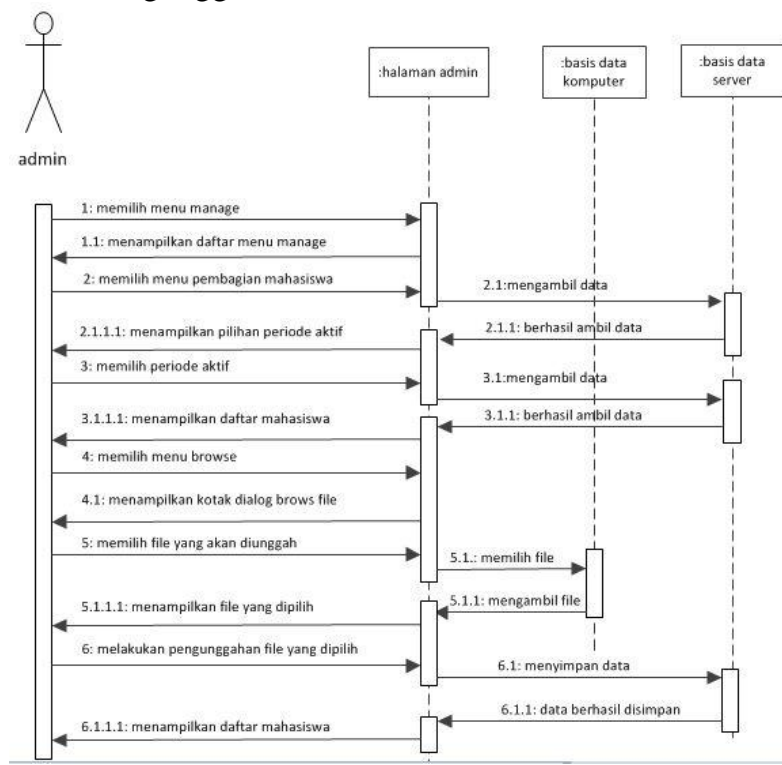

Gambar 7 Diagram sekuensial dari mengunggah data mahasiswa

Gambar 8 merupakan digram sekuensial dari mencetak nilai mahasiswa.

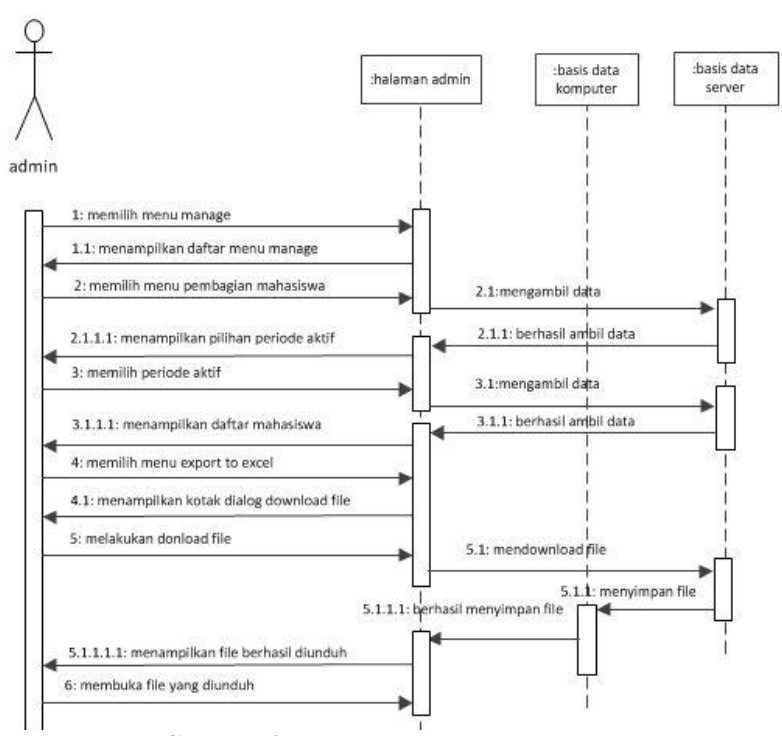

Gambar 8 Diagram sekuensial dari mengunggah data mahasiswa 


\section{IMPLEMENTASI DAN PENGUJIAN}

\section{A. Implementasi Basis Data}

Tahapan ini mengimplementasikan hasil perancangan basis pada sistem yang telah dibuat sebelumnya.

Gambar 9 merupakan contoh implementasi pada tabel admin.

\begin{tabular}{|c|c|c|c|c|c|}
\hline \# Name & Type & Collation & Attributes & Null & Default Extra \\
\hline 1 id_user & $\operatorname{varchar}(30)$ & latin1_swedish_ci & & No & None \\
\hline 2 password & varchar(32) & latin1_swedish_ci & & No & None \\
\hline 3 alias & $\operatorname{varchar}(30)$ & latin1_swedish_ci & & No & None \\
\hline 4 previleges & $\begin{array}{l}\text { enum('superadmin', 'admin', } \\
\text { 'tu', ") }\end{array}$ & latin1_swedish_ci & & No & None \\
\hline 5 status & enum(aktif, 'nonaktif, ", ") & latin1_swedish_ci & & No & None \\
\hline $6 \operatorname{tgl}$ & date & & & No & None \\
\hline
\end{tabular}

Implementasi tabel yang lain ditunjukkan oleh gambar 10 sampai dengan gambar 18 .

\begin{tabular}{|c|c|c|c|c|c|c|}
\hline \# Name & Type & Collation & Attributes & Null & Default & t Extra \\
\hline 1 id_periode & $\operatorname{int}(3)$ & & & No & None & AUTO_INCREMENT \\
\hline 2 nama & $\operatorname{varchar}(30)$ & latin1_swedish_ci & & No & None & \\
\hline 3 deskripsi & text & latin1_swedish_ci & & No & None & \\
\hline 4 status & $\begin{array}{l}\text { enum(aktif, } \\
\text { nonaktif, ",") }\end{array}$ & latin1_swedish_ci & & No & None & \\
\hline $5 \mathrm{tgl}$ & date & & & No & None & \\
\hline
\end{tabular}

\begin{tabular}{|c|c|c|c|c|c|}
\hline \# Name & Collation & Attributes & Null & Default & Extra \\
\hline 1 id_kab & $\operatorname{int}(3)$ & & No & None & AUTO_INCREMENT \\
\hline 2 nama & varchar(15) latin1_swedish ci & & No & None & \\
\hline $3 \operatorname{tgl}$ & date & & No & None & \\
\hline
\end{tabular}

\begin{tabular}{|c|c|c|c|c|c|c|}
\hline \# Name & Type & Collation & Attributes & Null & Default & Extra \\
\hline 1 id_kec & $\operatorname{int}(3)$ & & & No & None & AUTO_INCREMENT \\
\hline 2 nama & $\operatorname{varchar}(20)$ & latin1_swedish_ci & & No & None & \\
\hline 3 id_kab & $\operatorname{int}(3)$ & & & No & None & \\
\hline $4 \operatorname{tgl}$ & date & & & No & None & \\
\hline
\end{tabular}

Gambar 12 Implementasi tabel tkecamatan

\begin{tabular}{|c|c|c|c|c|c|}
\hline \# Name & Collation & Attributes & Null & Default & Extra \\
\hline 1 id_desa & $\operatorname{int}(3)$ & & No & None & AUTO_INCREMENT \\
\hline 2 nama & $\operatorname{varchar}(20)$ latin1_swedish_ci & & No & None & \\
\hline 3 id_kec & $\operatorname{int}(3)$ & & No & None & \\
\hline $4 \mathrm{tgl}$ & date & & No & None & \\
\hline
\end{tabular}

Gambar 13 Implementasi tabel tdesa

\begin{tabular}{|c|c|c|c|c|c|c|}
\hline \# Name & Type & Collation & Attributes & Null & Default & Extra \\
\hline 1 id_dpl & $\operatorname{int}(3)$ & & & No & None & AUTO_INCREMENT \\
\hline 2 nama & $\operatorname{varchar}(40)$ & latin1_swedish_ci & & No & None & \\
\hline 3 jurusan & $\operatorname{varchar}(30)$ & latin1_swedish_ci & & No & None & \\
\hline 4 fakultas & varchar(5) & latin1_swedish_ci & & No & None & \\
\hline $5 \operatorname{tgl}$ & date & & & No & None & \\
\hline
\end{tabular}

Gambar 14 Implementasi tabel tdpl

\begin{tabular}{|c|c|c|c|c|c|c|}
\hline \# Name & Type & Collation & Attributes & Null & Default & Extra \\
\hline 1 idpeserta & $\operatorname{int}(6)$ & & & No & None & AUTO_INCREMENT \\
\hline $2 \mathrm{nim}$ & $\operatorname{varchar}(14)$ & latin1_swedish_ci & & No & None & \\
\hline 3 nama & $\operatorname{varchar}(40)$ & latin1_swedish_ci & & No & None & \\
\hline 4 gender & $\operatorname{varchar(1)}$ & latin1_swedish_ci & & No & None & \\
\hline 5 idperiode & $\operatorname{int}(3)$ & & & No & None & \\
\hline 6 idwilayah & $\operatorname{int}(3)$ & & & Yes & NULL & \\
\hline 7 nilai & $\begin{array}{l}\text { enum('A', 'B', } \\
\text { 'C', 'D', 'E') }\end{array}$ & latin1_swedish_ci & & Yes & NULL & \\
\hline
\end{tabular}

Gambar 15 Implementasi tabel tmahasiswa

\begin{tabular}{|c|c|c|c|c|c|c|}
\hline \# Name & Type & Collation & Attributes & Null & Default & Extra \\
\hline 1 idpeserta & $\operatorname{int}(6)$ & & & No & None & AUTO_INCREMENT \\
\hline $2 \mathrm{nim}$ & $\operatorname{varchar}(14)$ & latin1_swedish_ci & & No & None & \\
\hline 3 nama & $\operatorname{varchar}(40)$ & latin1_swedish_ci & & No & None & \\
\hline 4 gender & $\operatorname{varchar}(1)$ & latin1_swedish_ci & & No & None & \\
\hline 5 idperiode & $\operatorname{int}(3)$ & & & No & None & \\
\hline 6 keterangan & $\begin{array}{l}\text { enum( }(0 \text { ", '1, } \\
\text { "2) }\end{array}$ & latin1_swedish_ci & & No & 0 & \\
\hline
\end{tabular}

Gambar 16 Implementasi tabel temp_mahasiswa

\begin{tabular}{|c|c|c|c|c|c|c|}
\hline \# Name & Type & Collation & Attributes & Null & Default & Extra \\
\hline 1 idwilayah & $\operatorname{int}(3)$ & & & No & None & AUTO_INCREMENT \\
\hline 2 idperiode & $\operatorname{int}(3)$ & & & No & None & \\
\hline 3 idkab & $\operatorname{int}(3)$ & & & No & None & \\
\hline 4 idkec & $\operatorname{int}(3)$ & & & No & None & \\
\hline 5 array_dpl & varchar(25) & ) latin1_swedish_ci & & Yes & NULL & \\
\hline
\end{tabular}

Gambar 17 Implementasi tabel twilayah

\begin{tabular}{|c|c|c|c|c|c|c|}
\hline \# Name & Type & Collation & Attributes & Null & Default & Extra \\
\hline 1 idwilayahdesa & $\operatorname{int}(3)$ & & & No & None & AUTO_INCREMENT \\
\hline 2 idwilayah & $\operatorname{int}(3)$ & & & No & None & \\
\hline 3 array_desa & varchat & ) latin1_swedish_ci & & Yes & NULL & \\
\hline
\end{tabular}

Gambar 18 Implementasi tabel tpembagiandesa

\section{B. Implementasi Antarmuka}

Berikut ini merupakan antarmuka yang dimiliki Aplikasi Administrasi Pengolahan Data KKN:

1. Halaman Login

Berisi form untuk melakukan login ke aplikasi dengan memasukkan username dan password, tampilan seperti pada gambar 19 .

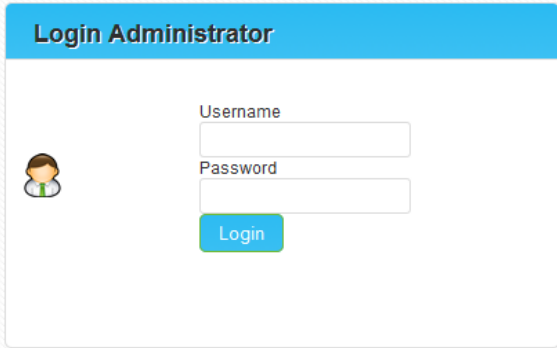

Gambar 19 Halaman Login

2. Halaman User

Berisi fitur untuk mengelola pengguna aplikasi, tampilan seperti pada Gambar 20.

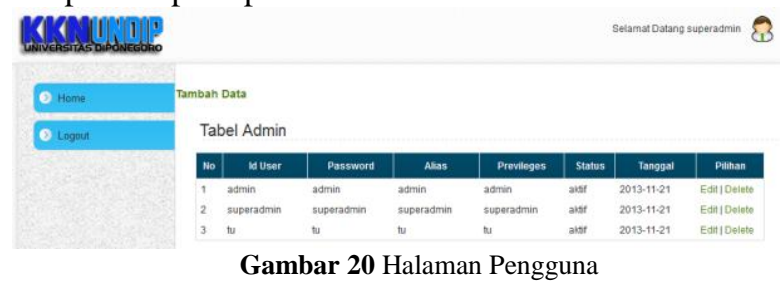




\section{Halaman Master DPL}

Berisi fitur untuk mengelola data DPL, tampilan seperti pada Gambar 21.

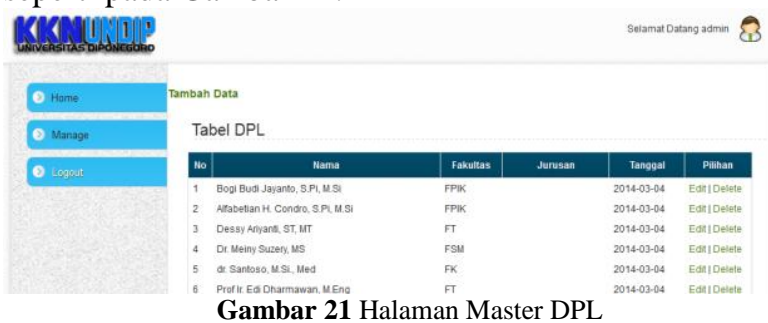

\section{Halaman Master Kabupaten}

Berisi fitur untuk mengelola data kabupaten, tampilan seperti pada Gambar 22.

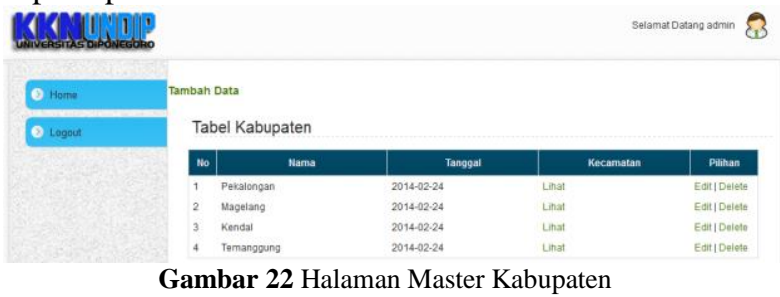

5. Halaman Master Kecamatan

Berisi fitur untuk mengelola data kecamatan, tampilan seperti pada Gambar 23.

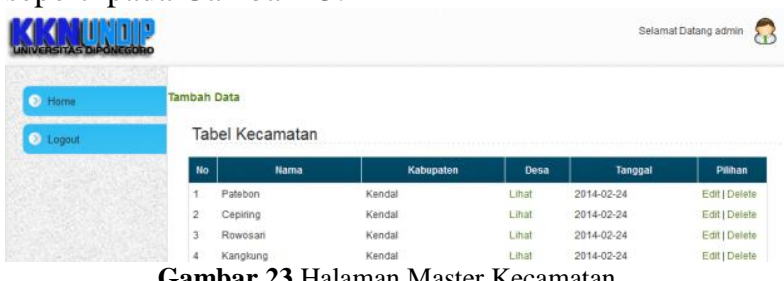

\section{Halaman Master Desa}

Berisi fitur untuk mengelola data desa, tampilan seperti pada Gambar 24.

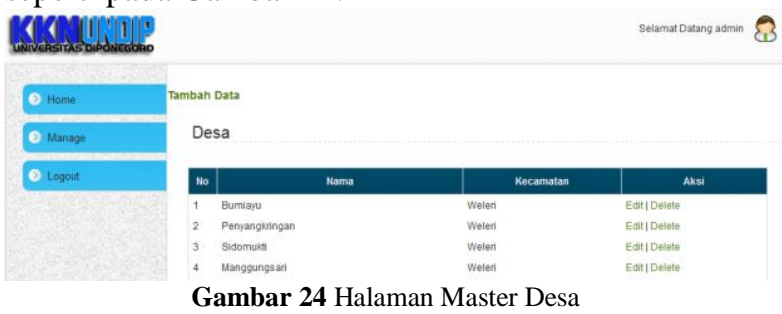

\section{Halaman Master Periode}

Berisi fitur untuk mengelola data periode, tampilan seperti pada Gambar 25.

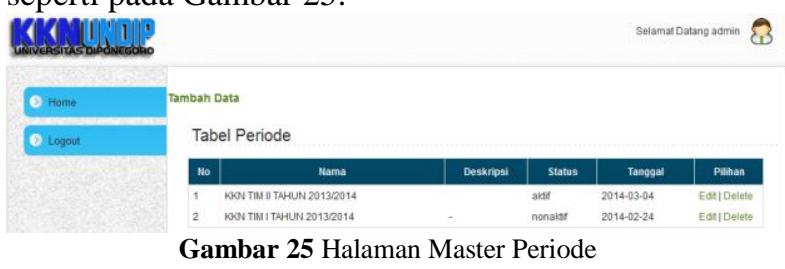

8. Halaman Pembagian Wilayah KKN

Berisi fitur untuk mengelola data wilayah, tampilan seperti pada Gambar 26.

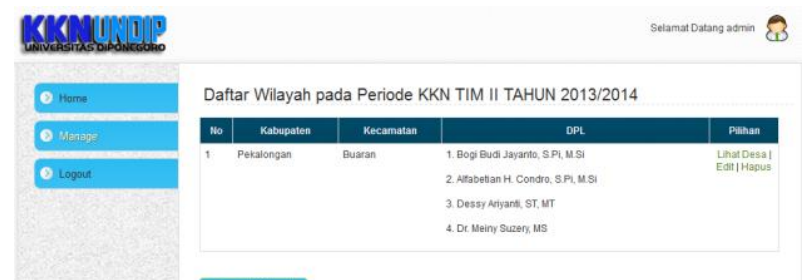

Gambar 26 Halaman Pembagian Wilayah

9. Halaman History Wilayah

Berisi fitur untuk mengelola data history wilayah, tampilan seperti pada Gambar 27.

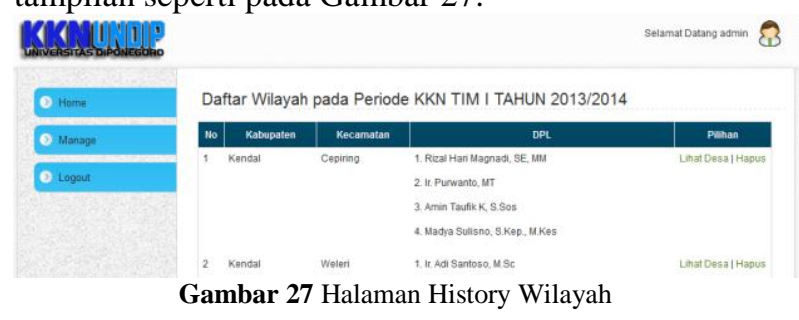

10. Halaman Pembagian Mahasiswa

Berisi fitur untuk mengelola data mahasiswa, tampilan seperti pada Gambar 28.

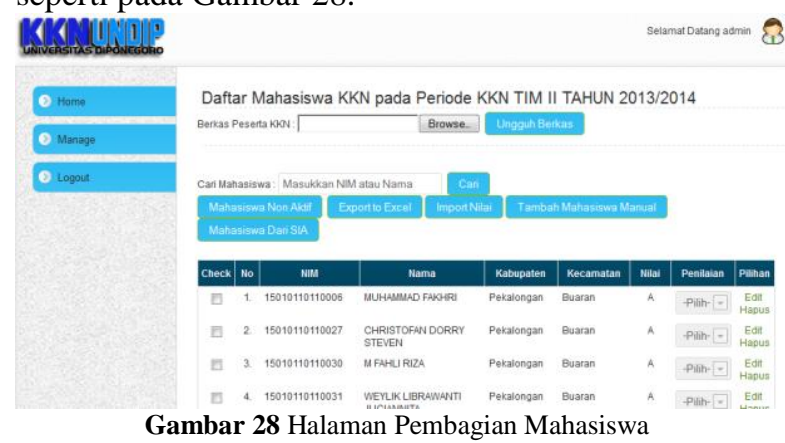

11. Halaman Upload Daftar Mahasiswa oleh Tata Usaha

Berisi fitur untuk mengunggah daftar peserta KKN, tampilan seperti pada Gambar 29.

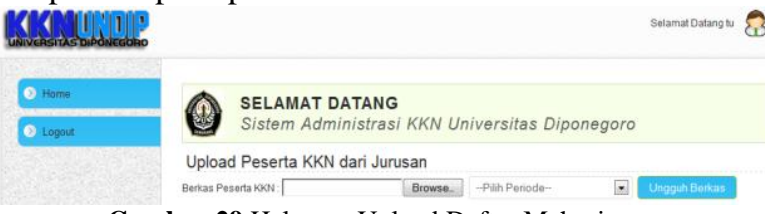

Gambar 29 Halaman Upload Daftar Mahasiswa

\section{Halaman Cari data oleh Mahasiswa}

Berisi fitur untuk mencari dan melihat data peserta KKN, tampilan seperti pada Gambar 30.

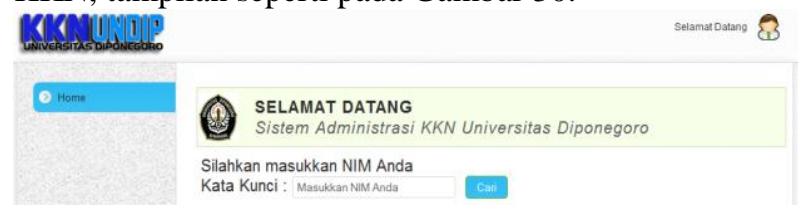

Gambar 30 Halaman Cari Data Mahasiswa 


\section{Pengujian}

Proses pengujian dilakukan menggunakan metode black-box berdasarkan fungsi dari aplikasi yang tertera pada diagram use case.

Tabel-tabel di bawah ini merupakan ringkasan dari pengujian yang telah dilakukan. Pertama adalah Tabel 1 yang merupakan ringkasan pengujian yang berhubungan dengan pengelolaan data User.

Tabel 1 Pengujian pengelolaan data User

\begin{tabular}{|c|c|c|c|}
\hline $\begin{array}{l}\text { Nama } \\
\text { Pengujian }\end{array}$ & $\begin{array}{l}\text { Bentuk } \\
\text { Pengujian }\end{array}$ & $\begin{array}{l}\text { Hasil yang } \\
\text { diharapkan }\end{array}$ & $\begin{array}{l}\text { Hasil } \\
\text { Pengujian }\end{array}$ \\
\hline $\begin{array}{l}\text { Pengujian } \\
\text { login }\end{array}$ & $\begin{array}{l}\text { Memasukkan } \\
\text { username dan } \\
\text { password yang } \\
\text { digunakan } \\
\text { untuk login }\end{array}$ & $\begin{array}{l}\text { Muncul halaman } \\
\text { utama } \text { user }\end{array}$ & Berhasil \\
\hline $\begin{array}{l}\text { Pengujian } \\
\text { tambah } \\
\text { data } \text { user }\end{array}$ & \begin{tabular}{l}
\multicolumn{2}{l}{ Memasukkan } \\
data pengguna \\
baru dan \\
menyimpannya
\end{tabular} & $\begin{array}{l}\text { Muncul pesan data } \\
\text { pengguna berhasil } \\
\text { ditambahkan dan } \\
\text { data tersebut tampil } \\
\text { pada daftar }\end{array}$ & Berhasil \\
\hline $\begin{array}{l}\text { Pengujian } \\
\text { ubah data } \\
\text { user }\end{array}$ & $\begin{array}{l}\text { Memilh data } \\
\text { pengguna yang } \\
\text { tersedia dan } \\
\text { mengubah } \\
\text { informasinya }\end{array}$ & $\begin{array}{l}\text { Muncul pesan data } \\
\text { pengguna berhasil } \\
\text { diperbarui dan data } \\
\text { yang baru muncul } \\
\text { dalam daftar }\end{array}$ & Berhasil \\
\hline $\begin{array}{l}\text { Pengujian } \\
\text { hapus data } \\
\text { user }\end{array}$ & $\begin{array}{l}\text { Memilih data } \\
\text { pengguna } \\
\text { tertentu dan } \\
\text { menghapus data } \\
\text { tersebut dengan } \\
\text { mengklik } \\
\text { tombol delete }\end{array}$ & \begin{tabular}{lr}
\multicolumn{2}{l}{ Muncul pesan data } \\
pengguna berhasil \\
dihapus dan data \\
yang & dihapus \\
menghilang & dari \\
daftar &
\end{tabular} & Berhasil \\
\hline
\end{tabular}

Tabel 2 merupakan ringkasan pengujian yang berhubungan dengan pengelolaan data periode.

\begin{tabular}{|c|c|c|c|}
\hline $\begin{array}{l}\text { ubah data } \\
\text { kabupaten }\end{array}$ & $\begin{array}{l}\text { kabupaten yang } \\
\text { tersedia dan } \\
\text { mengubah } \\
\text { informasinya }\end{array}$ & $\begin{array}{l}\text { kabupaten berhasil } \\
\text { diperbarui dan data } \\
\text { yang baru muncul } \\
\text { dalam daftar }\end{array}$ & \\
\hline $\begin{array}{l}\text { Pengujian } \\
\text { hapus data } \\
\text { kabupaten }\end{array}$ & $\begin{array}{l}\text { Memilih data } \\
\text { kabupaten } \\
\text { tertentu dan } \\
\text { menghapus data } \\
\text { tersebut dengan } \\
\text { mengklik } \\
\text { tombol delete }\end{array}$ & $\begin{array}{lr}\text { Muncul pesan data } \\
\text { kabupaten berhasil } \\
\text { dihapus dan data } \\
\text { yang } \\
\text { menghilang dihapus } \\
\text { daftar }\end{array}$ & Berhasil \\
\hline
\end{tabular}

Tabel 4 merupakan ringkasan pengujian yang berhubungan dengan pengelolaan data kecamatan.

Tabel 4 Pengujian pengelolaan data kecamatan

\begin{tabular}{|c|c|c|c|}
\hline $\begin{array}{l}\text { Nama } \\
\text { Pengujian }\end{array}$ & $\begin{array}{l}\text { Bentuk } \\
\text { Pengujian }\end{array}$ & $\begin{array}{l}\text { Hasil yang } \\
\text { diharapkan }\end{array}$ & $\begin{array}{l}\text { Hasil } \\
\text { Pengujian }\end{array}$ \\
\hline $\begin{array}{l}\text { Pengujian } \\
\text { tambah } \\
\text { data } \\
\text { kecamatan }\end{array}$ & $\begin{array}{l}\text { Memasukkan } \\
\text { data kecamatan } \\
\text { baru dan } \\
\text { menyimpannya }\end{array}$ & $\begin{array}{l}\text { Muncul pesan data } \\
\text { kecamatan berhasil } \\
\text { ditambahkan dan } \\
\text { data tersebut tampil } \\
\text { pada daftar }\end{array}$ & Berhasil \\
\hline $\begin{array}{l}\text { Pengujian } \\
\text { ubah data } \\
\text { kecamatan }\end{array}$ & $\begin{array}{l}\text { Memilh data } \\
\text { kecamatan yang } \\
\text { tersedia dan } \\
\text { mengubah } \\
\text { informasinya } \\
\end{array}$ & $\begin{array}{l}\text { Muncul pesan data } \\
\text { kecamatan berhasil } \\
\text { diperbarui dan data } \\
\text { yang baru muncul } \\
\text { dalam daftar }\end{array}$ & Berhasil \\
\hline $\begin{array}{l}\text { Pengujian } \\
\text { hapus data } \\
\text { kecamatan }\end{array}$ & $\begin{array}{l}\text { Memilih data } \\
\text { kecamatan dan } \\
\text { tertentu da } \\
\text { menghapus data } \\
\text { tersebut dengan } \\
\text { mengklik } \\
\text { tombol delete }\end{array}$ & $\begin{array}{lr}\text { Muncul pesan data } \\
\text { kecamatan berhasil } \\
\text { dihapus dan data } \\
\text { yang } & \text { dihapus } \\
\text { menghilang } & \text { dari } \\
\text { daftar } & \end{array}$ & Berhasil \\
\hline
\end{tabular}

Tabel 2 Pengujian pengelolaan data periode

\begin{tabular}{|c|c|c|c|}
\hline $\begin{array}{l}\text { Nama } \\
\text { Pengujian }\end{array}$ & $\begin{array}{l}\text { Bentuk } \\
\text { Pengujian }\end{array}$ & $\begin{array}{l}\text { Hasil yang } \\
\text { diharapkan }\end{array}$ & $\begin{array}{l}\text { Hasil } \\
\text { Pengujian }\end{array}$ \\
\hline $\begin{array}{l}\text { Pengujian } \\
\text { tambah } \\
\text { data } \\
\text { periode }\end{array}$ & \begin{tabular}{l}
\multicolumn{2}{l}{ Memasukkan } \\
data periode \\
baru dan \\
menyimpannya
\end{tabular} & $\begin{array}{l}\text { Muncul pesan data } \\
\text { periode berhasil } \\
\text { ditambahkan dan } \\
\text { data tersebut tampil } \\
\text { pada daftar }\end{array}$ & Berhasil \\
\hline $\begin{array}{l}\text { Pengujian } \\
\text { ubah data } \\
\text { periode }\end{array}$ & $\begin{array}{l}\text { Memilh data } \\
\text { periode yang } \\
\text { tersedia dan } \\
\text { mengubah } \\
\text { informasinya } \\
\end{array}$ & $\begin{array}{l}\text { Muncul pesan data } \\
\text { periode berhasil } \\
\text { diperbarui dan data } \\
\text { yang baru muncul } \\
\text { dalam daftar }\end{array}$ & Berhasil \\
\hline $\begin{array}{l}\text { Pengujian } \\
\text { hapus data } \\
\text { periode }\end{array}$ & $\begin{array}{l}\text { Memilih data } \\
\text { periode tertentu } \\
\text { dan menghapus } \\
\text { data tersebut } \\
\text { dengan } \\
\text { mengklik } \\
\text { tombol delete }\end{array}$ & $\begin{array}{lrr}\text { Muncul } & \text { pesan data } \\
\text { periode } & \text { berhasil } \\
\text { dihapus } & \text { dan data } \\
\text { yang } & \text { dihapus } \\
\text { menghilang } & \text { dari } \\
\text { daftar } & & \end{array}$ & Berhasil \\
\hline
\end{tabular}

Tabel 3 merupakan ringkasan pengujian yang berhubungan dengan pengelolaan data kabupaten.
Tabel 5 merupakan ringkasan pengujian yang berhubungan dengan pengelolaan data desa.

Tabel 5 Pengujian pengelolaan data desa

\begin{tabular}{|c|c|c|c|}
\hline $\begin{array}{l}\text { Nama } \\
\text { Pengujian }\end{array}$ & $\begin{array}{l}\text { Bentuk } \\
\text { Pengujian }\end{array}$ & $\begin{array}{l}\text { Hasil yang } \\
\text { diharapkan }\end{array}$ & $\begin{array}{l}\text { Hasil } \\
\text { Pengujian }\end{array}$ \\
\hline $\begin{array}{l}\text { Pengujian } \\
\text { tambah } \\
\text { data desa }\end{array}$ & $\begin{array}{l}\text { Memasukkan } \\
\text { data desa baru } \\
\text { dan } \\
\text { menyimpannya }\end{array}$ & $\begin{array}{l}\text { Muncul pesan data } \\
\text { desa berhasil } \\
\text { ditambahkan dan } \\
\text { data tersebut tampil } \\
\text { pada daftar }\end{array}$ & Berhasil \\
\hline $\begin{array}{l}\text { Pengujian } \\
\text { ubah data } \\
\text { desa }\end{array}$ & $\begin{array}{lr}\text { Memilh data } \\
\text { desa yang } \\
\text { tersedia dan } \\
\text { mengubah } \\
\text { informasinya }\end{array}$ & $\begin{array}{l}\text { Muncul pesan data } \\
\text { desa berhasil } \\
\text { diperbarui dan data } \\
\text { yang baru muncul } \\
\text { dalam daftar }\end{array}$ & Berhasil \\
\hline $\begin{array}{l}\text { Pengujian } \\
\text { hapus data } \\
\text { desa }\end{array}$ & $\begin{array}{l}\text { Memilih data } \\
\text { desa tertentu } \\
\text { dan menghapus } \\
\text { data tersebut } \\
\text { dengan } \\
\text { mengklik } \\
\text { tombol delete }\end{array}$ & $\begin{array}{lrr}\text { Muncul } & \text { pesan data } \\
\text { desa } & \text { berhasil } \\
\text { dihapus } & \text { dan data } \\
\text { yang } & \text { dihapus } \\
\text { menghilang } & \text { dari } \\
\text { daftar } & \end{array}$ & Berhasil \\
\hline
\end{tabular}

Tabel 3 Pengujian pengelolaan data kabupaten

\begin{tabular}{|c|c|c|c|c|c|c|c|}
\hline $\begin{array}{l}\text { Nama } \\
\text { Pengujian }\end{array}$ & $\begin{array}{l}\text { Bentuk } \\
\text { Pengujian }\end{array}$ & $\begin{array}{l}\text { Hasil yang } \\
\text { diharapkan }\end{array}$ & $\begin{array}{l}\text { Hasil } \\
\text { Pengujian }\end{array}$ & $\begin{array}{l}\text { Nama } \\
\text { Penguiian }\end{array}$ & $\begin{array}{l}\text { Bentuk } \\
\text { Pengujian }\end{array}$ & $\begin{array}{l}\text { ta dp1 } \\
\text { Hasil yang } \\
\text { diharapkan }\end{array}$ & $\begin{array}{l}\text { Hasil } \\
\text { Pengujian }\end{array}$ \\
\hline $\begin{array}{l}\text { Pengujian } \\
\text { tambah } \\
\text { data } \\
\text { kabupaten }\end{array}$ & $\begin{array}{l}\text { Memasukkan } \\
\text { data kabupaten } \\
\text { baru dan } \\
\text { menyimpannya }\end{array}$ & $\begin{array}{l}\text { Muncul pesan data } \\
\text { kabupaten berhasil } \\
\text { ditambahkan dan } \\
\text { data tersebut tampil } \\
\text { pada daftar }\end{array}$ & Berhasil & $\begin{array}{l}\text { Pengujian } \\
\text { tambah } \\
\text { data dpl }\end{array}$ & $\begin{array}{l}\text { Memasukkan } \\
\text { data dpl baru } \\
\text { dan } \\
\text { menyimpannya }\end{array}$ & $\begin{array}{lr}\text { Muncul pesan data } \\
\text { dpl berhasil } \\
\text { ditambahkan dan } \\
\text { data tersebut tampil } \\
\text { pada daftar }\end{array}$ & Berhasil \\
\hline
\end{tabular}

Tabel 6 merupakan ringkasan pengujian yang berhubungan dengan pengelolaan data dpl.

Tabel 6 Pengujian pengelolaan data dpl 


\begin{tabular}{|l|l|l|l|}
\hline $\begin{array}{l}\text { Pengujian } \\
\text { ubah data } \\
\text { dpl }\end{array}$ & $\begin{array}{l}\text { Memilh data dpl } \\
\text { yang tersedia } \\
\text { dan mengubah } \\
\text { informasinya }\end{array}$ & $\begin{array}{l}\text { Muncul pesan data } \\
\text { dpl berhasil } \\
\text { diperbarui dan data } \\
\text { yang baru muncul } \\
\text { dalam daftar }\end{array}$ & Berhasil \\
\hline $\begin{array}{l}\text { Pengujian } \\
\text { hapus data } \\
\text { dpl }\end{array}$ & $\begin{array}{l}\text { Memilih data } \\
\text { dpl tertentu dan } \\
\text { menghapus data } \\
\text { tersebut dengan } \\
\text { mengklik } \\
\text { tombol delete }\end{array}$ & $\begin{array}{l}\text { Muncul pesan data } \\
\text { dpl berhasil dihapus } \\
\text { dan data yang } \\
\text { dihapus menghilang } \\
\text { dari daftar }\end{array}$ & Berhasil \\
\hline
\end{tabular}

Tabel 7 merupakan ringkasan pengujian yang berhubungan dengan pengelolaan data mahasiswa.
Tabel 9 Pengujian pengelolaan data wilayah

\begin{tabular}{|c|c|c|c|}
\hline $\begin{array}{l}\text { Nama } \\
\text { Pengujian }\end{array}$ & $\begin{array}{l}\text { Bentuk } \\
\text { Pengujian }\end{array}$ & $\begin{array}{l}\text { Hasil yang } \\
\text { diharapkan }\end{array}$ & $\begin{array}{l}\text { Hasil } \\
\text { Pengujian }\end{array}$ \\
\hline $\begin{array}{l}\text { Pengujian } \\
\text { tambah } \\
\text { data } \\
\text { wilayah }\end{array}$ & \begin{tabular}{l}
\multicolumn{2}{l}{ Memasukkan } \\
data wilayah \\
baru dan \\
menyimpannya
\end{tabular} & $\begin{array}{l}\text { Muncul pesan data } \\
\text { wilayah berhasil } \\
\text { ditambahkan dan } \\
\text { data tersebut tampil } \\
\text { pada daftar }\end{array}$ & Berhasil \\
\hline $\begin{array}{l}\text { Pengujian } \\
\text { ubah data } \\
\text { wilayah }\end{array}$ & $\begin{array}{l}\text { Memilh data } \\
\text { wilayah yang } \\
\text { tersedia dan } \\
\text { mengubah } \\
\text { informasinya } \\
\end{array}$ & $\begin{array}{l}\text { Muncul pesan data } \\
\text { wilayah berhasil } \\
\text { diperbarui dan data } \\
\text { yang baru muncul } \\
\text { dalam daftar }\end{array}$ & Berhasil \\
\hline $\begin{array}{l}\text { Pengujian } \\
\text { hapus data } \\
\text { wilayah }\end{array}$ & $\begin{array}{l}\text { Memilih data } \\
\text { wilayah tertentu } \\
\text { dan menghapus } \\
\text { data tersebut } \\
\text { dengan } \\
\text { mengklik } \\
\text { tombol hapus }\end{array}$ & \begin{tabular}{lr} 
Muncul & pesan data \\
wilayah & \multicolumn{2}{c}{ berhasil } \\
dihapus & dan data \\
yang & dihapus \\
menghilang & dari \\
daftar &
\end{tabular} & Berhasil \\
\hline
\end{tabular}

Tabel 7 Pengujian pengelolaan data mahasiswa

\begin{tabular}{|c|c|c|c|}
\hline $\begin{array}{l}\text { Nama } \\
\text { Pengujian }\end{array}$ & $\begin{array}{l}\text { Bentuk } \\
\text { Pengujian }\end{array}$ & $\begin{array}{l}\text { Hasil yang } \\
\text { diharapkan }\end{array}$ & $\begin{array}{l}\text { Hasil } \\
\text { Pengujian }\end{array}$ \\
\hline $\begin{array}{l}\text { Pengujian } \\
\text { tambah } \\
\text { data } \\
\text { mahasiswa }\end{array}$ & $\begin{array}{l}\text { Memasukkan } \\
\text { data mahasiswa } \\
\text { baru dan } \\
\text { menyimpannya }\end{array}$ & $\begin{array}{l}\text { Muncul pesan data } \\
\text { mahasiswa berhasil } \\
\text { ditambahkan dan } \\
\text { data tersebut tampil } \\
\text { pada daftar }\end{array}$ & Berhasil \\
\hline $\begin{array}{l}\text { Pengujian } \\
\text { ubah data } \\
\text { mahasiswa }\end{array}$ & $\begin{array}{l}\text { Memilh data } \\
\text { mahasiswa yang } \\
\text { tersedia dan } \\
\text { mengubah } \\
\text { informasinya }\end{array}$ & $\begin{array}{l}\text { Muncul pesan data } \\
\text { mahasiswa berhasil } \\
\text { diperbarui dan data } \\
\text { yang baru muncul } \\
\text { dalam daftar }\end{array}$ & Berhasil \\
\hline $\begin{array}{l}\text { Pengujian } \\
\text { hapus data } \\
\text { mahasiswa }\end{array}$ & $\begin{array}{l}\text { Memilih data } \\
\text { mahasiswa } \\
\text { tertentu dan } \\
\text { menghapus data } \\
\text { tersebut dengan } \\
\text { mengklik } \\
\text { tombol hapus }\end{array}$ & $\begin{array}{lr}\text { Muncul pesan data } \\
\text { mahasiswa berhasil } \\
\text { dihapus dan data } \\
\text { yang dihapus } \\
\text { menghilang } \\
\text { daftar }\end{array}$ & Berhasil \\
\hline $\begin{array}{l}\text { Pengujian } \\
\text { unggah } \\
\text { data } \\
\text { mahasiswa }\end{array}$ & $\begin{array}{l}\text { Mengunggah } \\
\text { berkas excel } \\
\text { yang berisi data } \\
\text { mahasiswa }\end{array}$ & $\begin{array}{lr}\text { Muncul } & \text { pesan } \\
\text { berkas } & \text { berhasil } \\
\text { diunggah dan data } \\
\text { yang ada didalam } \\
\text { berkas } & \text { tersebut } \\
\text { muncul dalam daftar }\end{array}$ & Berhasil \\
\hline $\begin{array}{l}\text { Pengujian } \\
\text { mencari } \\
\text { data } \\
\text { mahasiswa }\end{array}$ & $\begin{array}{l}\text { Memasukkan } \\
\text { kata kunci } \\
\text { pencarian } \\
\text { (nama atau nim) } \\
\text { pada kotak isian } \\
\text { yang ada }\end{array}$ & \begin{tabular}{lr} 
Data & mahasiswa \\
yang & berhubungan \\
dengan kata kunci \\
yang ditampilkan \\
\multicolumn{2}{l}{ dalam daftar }
\end{tabular} & Berhasil \\
\hline
\end{tabular}

Tabel 8 merupakan ringkasan pengujian yang berhubungan dengan pengelolaan data nilai mahasiswa.

Tabel 8 Pengujian pengelolaan data nilai mahasiswa

\begin{tabular}{|l|l|l|l|}
\hline $\begin{array}{l}\text { Nama } \\
\text { Pengujian }\end{array}$ & $\begin{array}{l}\text { Bentuk } \\
\text { Pengujian }\end{array}$ & $\begin{array}{l}\text { Hasil yang } \\
\text { diharapkan }\end{array}$ & $\begin{array}{l}\text { Hasil } \\
\text { Pengujian }\end{array}$ \\
\hline $\begin{array}{l}\text { Pengujian } \\
\text { unggah } \\
\text { data nilai } \\
\text { mahasiswa }\end{array}$ & $\begin{array}{l}\text { Mengunggah } \\
\text { berkas excel } \\
\text { yang berisi data } \\
\text { nilai } \\
\text { mahasiswa }\end{array}$ & $\begin{array}{l}\text { Muncul pesan } \\
\text { berkas berhasil } \\
\text { diunggah dan data } \\
\text { yang ada didalam } \\
\text { berkas tersebut } \\
\text { muncul dalam daftar }\end{array}$ & Berhasil \\
\hline $\begin{array}{l}\text { Pengujian } \\
\text { mencetak } \\
\text { data nilai } \\
\text { mahasiswa }\end{array}$ & $\begin{array}{l}\text { Mengklik } \\
\text { tombol export } \\
\text { to excel }\end{array}$ & $\begin{array}{l}\text { Muncul kotak dialog } \\
\text { download file excel } \\
\text { dan file tersebut } \\
\text { muncul pada daftar } \\
\text { downloads serta } \\
\text { dapat dibuka }\end{array}$ & Berhasil \\
\hline
\end{tabular}

Tabel 9 merupakan ringkasan pengujian yang berhubungan dengan pengelolaan data wilayah.
Tabel 10 merupakan ringkasan pengujian yang berhubungan dengan pengelolaan data history wilayah.

Tabel 10 Pengujian pengelolaan data history wilayah

\begin{tabular}{|l|l|l|l|}
\hline $\begin{array}{l}\text { Nama } \\
\text { Pengujian }\end{array}$ & $\begin{array}{l}\text { Bentuk } \\
\text { Pengujian }\end{array}$ & $\begin{array}{l}\text { Hasil yang } \\
\text { diharapkan }\end{array}$ & $\begin{array}{l}\text { Hasil } \\
\text { Pengujian }\end{array}$ \\
\hline $\begin{array}{l}\text { Pengujian } \\
\text { melihat } \\
\text { data } \\
\text { history } \\
\text { wilayah }\end{array}$ & $\begin{array}{l}\text { Memilih menu } \\
\text { record wilayah }\end{array}$ & $\begin{array}{l}\text { Muncul data history } \\
\text { wilayah yang } \\
\text { digunakan pada } \\
\text { periode sebelumnya }\end{array}$ & Berhasil \\
\hline $\begin{array}{l}\text { Pengujian } \\
\text { hapus data } \\
\text { history } \\
\text { wilayah }\end{array}$ & $\begin{array}{l}\text { Memilih data } \\
\text { history wilayah } \\
\text { tertentu dan } \\
\text { menghapus data } \\
\text { tersebut dengan } \\
\text { mengklik } \\
\text { tombol hapus }\end{array}$ & $\begin{array}{l}\text { Muncul pesan data } \\
\text { wilayah berhasil } \\
\text { dihapus dan data } \\
\text { yang dihapus } \\
\text { menghilang dari } \\
\text { daftar B }\end{array}$ & Berhasil \\
\hline
\end{tabular}

\section{PENUTUP}

Kesimpulan dan saran dari hasil penelitian dan pembahasan adalah sebagai berikut.

\section{A. Kesimpulan}

Berdasarkan hasil penelitian dan pembahasan, maka dapat diambil kesimpulan sebagai berikut :

1) Aplikasi administrasi pengolahan data $\mathrm{KKN}$ dapat melakukan pengelolaan data KKN yang meliputi data kabupaten, data kecamatan, data desa, data periode, data DPL, data mahasiswa, serta data wilayah.

2) Berdasarkan data sampel kegiatan $\mathrm{KKN}$ yang telah digunakan pada aplikasi, aplikasi tersebut dapat berjalan dengan baik yaitu dapat dapat melakukan pengelolaan data KKN yang meliputi data kabupaten, data kecamatan, data desa, data periode, data DPL, data mahasiswa, serta data wilayah.

3) Aplikasi administrasi pengolahan data KKN memiliki fitur untuk mengekspor nilai dan daftar mahasiswa yang lolos, tidak lolos dan mengundurkan diri dari kegiatan KKN yang telah selesai dilakukan ke dalam bentuk file excel, sehingga file tersebut dapat dimasukkan kedalam laporan kegiatan KKN. 
4) Aplikasi administrasi pengolahan data KKN juga memiliki fitur untuk mengunggah data peserta KKN yang didapat dari SIAKAD.

\section{B. Saran}

Terdapat saran dari hasil penelitian yaitu sebagai berikut :

1) Aplikasi administrasi pengolahan data $\mathrm{KKN}$ ini dapat dikembangkan lebih lanjut dengan menambahkan fitur mengambil data peserta KKN dari SIAKAD secara langsung dengan menambahkan fitur web services ke dalam aplikasi untuk menjaga keamanan dan kerahasiaan data SIAKAD

\section{DAFTAR PUSTAKA}

[1] A.S, Rosa dan Shalahuddin, M., Modul Pembelajaran Rekayasa Perangkat Lunak (Terstruktur dan Berorientasi Objek), Modula, Bandung, 2011.

[2] Adi, A.P dan Sanjay, R., Web Makin Dahsyat dengan JQuery, Kompas Gramedia. Semarang, 2012.

[3] Bin Ladjamudin, Al-Bahra, Analisis dan Desain Sistem Informasi, Graha Ilmu, Yogyakarta, 2005.

[4] Gata, Windu dan Gata, Grace., Sukses Membangung Aplikasi Penjualan dengan Java, PT Elex Media Komputindo, Jakarta, 2013.
[5] Hirin A.M dan Virgi., Cepat Mahir Pemrograman Web dengan PHP dan MySQL, Prestasi Pustakaraya, Jakarta, 2011.

[6] Huda, Miftahul., Membuat Aplikasi Database dengan Java, MySQL dan Netbeans, PT. Elex Media Komputindo, Jakarta, 2010.

[7] Kadir, Abdul., Dasar Pemrograman Web Dinamis Menggunakan PHP, CV. Andi Offset, Yogyakarta, 2008.

[8] Pribadi Basuki, Awan, Membangun Web Berbasis PHP dengan Framework CodeIgniter, Lokomedia, Yogyakarta, 2010.

[9] Riyanto, Slamet, Membangun Web Portal Multibahasa Joomla 1.5X+CD, PT. Elex Media Komputindo, Jakarta, 2009.

[10] Septian, Gungun. Trik Pintar Menguasai CodeIgniter, PT. Elex Media Komputindo, Jakarta, 2011.

[11] Shodiq, Muchamad, Simbes, Aplikasi Manajemen Beasiswa di Universitas Diponegoro Berbasis Framework Code Igniter dan MySQL, Skripsi S-1, Universitas Diponegoro, Semarang, 2013.

[12] Sutanta, Edhy, Sistem Informasi Manajemen, Graha Ilmu, Yogyakarta, 2003

[13] Taylor, PhD, David A., Object-Oriented Information System: Planning and Implementation, John Wiley \& Sons, Inc., Canada, 1992.

[14] Wahyono, Teguh., Practice Guide PHP On Windows, PT. Elex Media Komputindo, Jakarta, 2009.

[15] Wicaksono, Diaz, Aplikasi Manajemen Praktikum Laboratorium Software Engineering Sistem Komputer Universitas Diponegoro, Skripsi S-1, Universitas Diponegoro, Semarang, 2014.

[16] Wiswakarma, Komang., 9 Langkah Menjadi Master Framework CodeIgniter., Loko Media, Yogyakarta, 2010. 